\title{
RESET
}

Recherches en sciences sociales sur Internet

\section{Extending the Study of Videogame Dependency}

Social Meaningfulness of "Addictive" Gaming and Self-analyses of Dependency

Elargir l'étude de la dépendance aux jeux vidéo. Signification sociale des pratiques " addictives» de jeu et auto-analyses de la dépendance.

\section{Nadine Jukschat}

\section{CpenEdition}

\section{Journals}

Electronic version

URL: http://journals.openedition.org/reset/120

DOI: $10.4000 /$ reset. 120

ISSN: 2264-6221

Publisher

Association Recherches en sciences sociales sur Internet

Electronic reference

Nadine Jukschat, " Extending the Study of Videogame Dependency », RESET [Online], 2 | 2013, Online since 01 July 2013, connection on 09 October 2020. URL : http://journals.openedition.org/reset/120 ; DOI : https://doi.org/10.4000/reset.120

This text was automatically generated on 9 October 2020 .

(C) Association Recherches en sciences sociales sur Internet 


\title{
Extending the Study of Videogame Dependency
}

\author{
Social Meaningfulness of "Addictive" Gaming and Self-analyses of \\ Dependency \\ Elargir l'étude de la dépendance aux jeux vidéo. Signification sociale des \\ pratiques « addictives » de jeu et auto-analyses de la dépendance.
}

\author{
Nadine Jukschat
}

\section{Introduction}

1 In the recent past, a phenomenon called video game dependency (sometimes also referred to as internet dependency) has attracted great attention in science and research, clinical practice and the media. The debate on this new phenomenon does not however seem to do justice to its complexity. For example, the research field - as with research on mental disorders in general (see Groenemeyer, 2008) - is dominated by medical-psychiatric thinking. The prevailing psychological and neuroscientific studies focus in particular on diagnosis and epidemiology, and largely use learning theory and neurobiology models to explain the occurrence and the process of video game and internet dependency (Gentile et al., 2011; Griffiths \& Hunt, 1998; Rehbein, Kleimann \& Mößle, 2010; Rumpf et al. 2011; Thalemann, Wölfling \& Grüsser, 2007). And even though researchers in this field do assume a multifactorial model of dependency development which includes the physical and social setting as determinants (Grüsser and Thalemann 2006), this is hardly taken into account or played down in concrete research practice ${ }^{1}$ (Gentile et al. 2011; Griffiths \& Hunt , 1998; Rehbein, Kleimann \& Mößle, 2010; Rumpf et al., 2011; Thalemann, Wölfling \& Grüsser, 2007).

2 Sociology and related disciplines in human and social studies on the other hand hardly pay any attention to the phenomenon, ignore or even negate its existence (Cover, 2006). There are only few exceptions: building on a constructivist perspective, for example, Cover (2006) investigates the "production of the gamer addiction myth" and 
concludes that "[g]aming is understood as addictive not because games are compulsively used, but because in representing their conceptual universe as "unreal" they are likened to drugs, and thereby become subjected to a discourse of drug addiction" (Cover, 2006). Walter and Schetsche (2003) show how internet dependency as a social problem evolved historically and describe the career of problem perception. To my knowledge, so far, no research exists which takes up former social sciences research on (drug) dependency and goes beyond this discourse-analytical/historical perspective to examine and reconstruct the empirical phenomenon itself form a social science perspective, analysing for example why and how people develop a gaming or online practice regarded as problematic and why and how they are labelled as addicts. Instead, sociology and related disciplines in human and social studies, and the young discipline of 'game studies' in particular, are very productive analysing the immanent behaviour patterns and interactions within the gaming and online worlds or investigating the positive aspects of their use (Corneliussen \& Rettberg, 2008; Fritz et al., 2011; Taylor, 2009). The field of video game and internet dependency is left to the more natural science and biomedicine-focused disciplines. This can be viewed as an unnecessary thematic self-exclusion of sociology regarding its fruitful former discussion and analyses of dependency in general.

The aim of this article is to show how sociology and related disciplines in human and social sciences could enrich the debate and contribute to a more differentiated understanding of the phenomenon. In a first step I want to highlight how sociologists have already looked at dependency in general. These perspectives could be fruitfully taken up also for researching this new phenomenon. The second and main focus of the article is on initial analyses from a German empirical research project, which includes 15 biographical narrative interviews (Przyborski \& Wohlrab-Sahr, 2008, 92 ff.; Schütze, 1983) with video gamers of both sexes who, according to the CSAS-II screening instrument $^{2}$ and/or self-analysis, are currently video game dependent or have been at some time in the past. These analyses show that regarding the behaviour commonly described as video game dependency (VGD) ${ }^{3}$, we are in fact dealing with a phenomenon with strong social implications which therefore deserves a sociological consideration. But rather than presenting an established research strategy for VGD or even developing a complete sociological theory on VGD the aim of this article is to highlight empirically how the human and social sciences could contribute to a more complex description and understanding of the behaviour called VGD and to plea for more theoretical thinking and qualitative empirical research on the phenomenon.

\section{Social Sciences and Dependency - a Mostly Forgotten Tradition}

4 Sociology and the social sciences as research disciplines have a tradition of addressing the subject of dependency. Although one cannot talk of the development of comprehensive sociological theories when it comes to the issue of dependency, it is possible - similar to the analysis of mental disorders in general (see Groenemeyer, 2008) - especially for the 1960s, 1970 s and 1980s, to argue that the phenomenon has indeed been addressed, primarily as part of the analysis of deviant behaviour (Dollinger, 2002; Dollinger \& Schmidt-Semisch, 2007; Schmerl, 1984; Schmidt, AlteTeigeler \& Hurrelmann, 1999). A basic distinction can be made here between more 
sociostructural approaches and social labelling approaches (Schmidt, Alte-Teigeler \& Hurrelmann, 1999).

5 The former are more concerned with etiology, i.e. the cultural and social conditions under which behavioural patterns can evolve. They understand dependency as a reaction to reduced chances in society (strain theory) or look at the close social surroundings (peer and parental influence) that might lead to dependency. For example, research conducted by Norman E. Zinberg assumes a multifactorial model of dependency development in which "drug, set and setting" (Zinberg, 1984) interact. He emphasizes the role of social norms, rules and rituals and thus the setting aspect. The work of well-known addiction-researcher Stanton Peele also follows this approach. For him, social structural conditions, i.e. the social milieu as well as situational factors play an important role. Thereby Peele sees dependency as functionalistic: "addiction is best understood as an individual's adjustment, albeit a self-defeating one, to his or her environment" (Peele 1985: 2). In addition he assumes that all forms of experience can produce dependency: "whether precipitated by a psychoactive drug or by the feelings associated with an intimate relationship" (Peele \& Brodsky, 1991: 5).

6 The labelling approach sees dependency more as the result of social interaction and thus takes in how this behaviour is seen as deviant (and thus how it comes about in the first place). Greater importance is attached to the process of how the phenomenon came to be seen and to authority of definition and evaluation; both: historically and on a microsociological level. One of the first and the most prominent representative of this research tradition is Howard Becker, who developed these processes using the example of marihuana users and defined deviant behaviour as "behaviour that people so label" (Becker, 1963: 9). The strength of this approach lies in its process orientation and its assumption of a contingent development rather than a deterministic one, i.e. the idea that entering the addictive cycle does not necessarily mean entering a one-way street desistance and remission are possible. Furthermore the labelling approach opens the possibility to go way beyond what Marlene Stein-Hilbers first criticized as the deficiency model as early as 1985 ("Defekt-Modell", Stein-Hilbers, 2007: 36) in her classical paper on "self-reflective approaches in drug-related research": This is an understanding which reduces the evolvement of addictive behaviour to the accumulation of statistical risk factors (of the person, the drug or the social situation) (see Stein-Hilbers 2007). With its focus on processes and careers the labelling approach, instead, allows analysis of the interaction between the subject perspective and the structural preconditions (Dollinger, 2002) and therefore allows insights into the concrete mechanisms of action.

7 With the resurgence of psychiatry following the invention and marketing of psychopharmaceutical products back in the 1960s, the paradigm shift in relation to psychiatric diagnostics with the third version of Diagnostic and Statistical Manual of Mental Disorders (DSM) in 1980, the rediscovery of the inheritance notion and the boom of neurophysiological brain research since the 1990s, the biomedical model began to dominate, while sociologists and scientists from related disciplines withdrew more and more from the research field ${ }^{4}$ (Gronemeyer, 2008; Hohl \& Keupp, 1991; Lane, 2006). There are only few attempts to counter this development, which has been criticised by Zinberg as early as the start of the 1980s: "The role of the environment continues to be played down, because research largely focuses on either the pharmaceutical characteristics of the drug and their associated health risks or on personality 
disintegration in individuals who fail to keep their use of the drug under control" 5 (Zinberg, 1983: 256). A few years later Hohl and Keupp still criticize that, with respect to psychological disturbance in general: "The hegemony [of objectivistic psychopathology] resulted in a failure to carry out a precise phenomenological reconstruction of psychological disorders, and particularly a reconstruction of the subjective relevance of that psychological deviance for the person involved, their relatives and other people they share their daily lives with"6 (Hohl \& Keupp, 1991: 316).

As early as 1985, Helene Stein-Hilbers argued for a multifaceted, nuanced and selfreflected approach in drug-related research which includes the human and social sciences perspective: "It goes without saying that this includes the precise and detailed analysis of socio-economic factors, psychological dispositions and of experienced psychological strain in the consumer's life history. The analysis of drug dependency needs to be as multifaceted and nuanced as reality itself"' (Stein-Hilbers, 2007: 44). And in one of the few recent anthologies on addiction-research from a social-science perspective, Dollinger and Schmidt-Semisch state that such research should analyze addiction always as a result of inter-personal communication, socio-cultural developments and constellations of power (Dollinger \& Schmidt-Semisch, 2007: 8).

\section{Research Question and Method}

The research project presented here tries to take up some of these sociological reflections and to transfer them to the phenomenon under debate since the 1990s: video game resp. internet dependency. It is a doctoral project conducted as part of a study done by the Criminological Research Institute of Lower Saxony and launched in summer 2010. The project uses biographic-narrative interviews (Hermanns, 1991; Küsters, 2009; Przyborski \& Wohlrab-Sahr, 2008; Schütze, 1983) a number of which were conducted with male and female video gamers who are or were at some point classed as video game dependent according to the CSAS-II screening instrument and/or self-analysis. The reconstructive analysis attempts to supplement the purely biomedical and psychological treatment of the phenomenon with a sociological perspective and investigates the question of the evolvement of the behaviour commonly called video game dependency (VGD) from a social science perspective. Dependency, from this perspective, is less understood as mental disorder or illness but as deviant behaviour, "insofar as the addict transgresses the boundaries and rules for dealing with the addictive substance accepted by society" ${ }^{8}$ (Kloppe, 2004: 282). Whereas within psychology and neuroscience scientists debate the right clinical term for the phenomenon and its correct classification within the diagnostic manuals (Kuss \& Griffiths, 2012) or try to investigate statistical risk factors for becoming dependent on video games using quantitative studies (Gentile et al., 2011; Griffiths \& Hunt, 1998; Rehbein, Kleimann \& Mößle, 2010; Rumpf et al. 2011; Thalemann, Wölfling \& Grüsser, 2007), the goal of this study is to take one step back: In the tradition of Clifford Geertz it wants "to figure out what the hell is going on" (Olson, 1991: 248) when people become heavily involved in video games so that their gaming behavior is considered a "dependency" and therefore a social problem. Starting with this curiosity the aim is to contribute to a more complex understanding of the phenomenon by taking the video gamers seriously and, in particular, placing the spotlight on the complex interrelationship between everyday life and the biography and the virtual world. The 
study asks how the gaming practice fits into the gamer's life, which every day and lifestyle problems can be solved using the virtual practices (and therefore leads to its maintenance) and what the intensive engagement with video games does to the player.

As regards methodology, the research process follows the grounded theory (Strauss 1998; Przyborski \& Wohlrab-Sahr, 2008) and in the analysis also uses the method of objective hermeneutics, which is currently one of the most prominent approaches in qualitative research in German-speaking countries (Oevermann et al., 1979; Przyborski \& Wohlrab-Sahr, 2008; Wernet, 2006). Both approaches reach way beyond paraphrasing the manifest text. Their goal is to reconstruct the latent patterns from the material, or, as Jo Reichertz puts it for objective hermeneutics: "the 'reconstruction of objective meaning structures' of texts: what the text producers thought, wished, hoped, believed in the creation of their text, that is, what subjective intentions they had, was - and is unimportant for objective hermeneutics" (Reichertz, 2004: 290). What the interviewees themselves say on a manifest level, and how they interpret it, is less important than the latent functionalities of their virtual practices regarding their everyday life and biography, which they themselves might not be aware of ${ }^{9}$. These latent patterns are reconstructed in team sessions using a microscopic, sequential analysis and constant comparison technique (for a detailed description of the procedure see Oevermann et al., 1979; Przyborski \& Wohlrab-Sahr, 2008; Wernet, 2006).

11 To find participants for the study, a wide range of recruitment strategies was used in search of gamers of all age groups and gaming habits. In order to minimize framing or bias on addiction beforehand, the study was advertised with the broad slogan "Gaming in Germany - between leisure-time activity and addiction". Information about it was spread in online and offline media, in internet forums and at important events in the gamer's scene. In addition, it was advertised at schools and universities and through gatekeepers including the German association for media addiction ("Fachverband Medienabhängigkeit") to find interviewees. Interested gamers were asked to complete an online screening questionnaire which besides questions regarding gaming habits and social figures included KFN's CSAS-II scale ${ }^{10}$ (Rehbein et al., 2010) for VGD and they were offered an incentive of 25 Euro for participation. In this way a database could be built up which in the end included around 1.100 gamers, with about 300 of them present or former addicts according to CSAS-II ${ }^{11}$. From this pool interviewees were selected, whereby according to theoretical sampling strategy results from first data analysis influenced the selection of the next interviewees (see Strauss 1998; Przyborski and Wohlrab-Sahr 2008).

By now 24 gamers - 15 of them classified as dependent - have been interviewed. All biographical narrative interviews started with a question inviting the interviewee to tell the story of her/his life, emphasizing a particular interest in the person "behind" the gamer, again, to minimize framing on gaming and addiction. The interviews were conducted in the private setting of the interviewees or at places chosen by the interviewees. Duration was between one and almost four hours.

\section{Two Case Studies and Their Theoretical Implications}

13 In this section, two case studies are portrayed. They were selected for presentation because although sharing the same "diagnosis" - Mathias scores "dependent" on the CSAS-II screening instrument, and Simone "ex-dependent" - they contrast in various 
ways: Regarding their gaming habits, their self-descriptions as gamers and the role gaming takes on in their everyday lives.

Each case is presented using a brief case outline in a biographical format which according to objective hermeneutics includes the "objective facts" of the biography and follows the interviewee's self-presentation ${ }^{12}$. After describing the gaming practice, in a first step the interpretation focuses on the level of self-analysis by the interviewees with respect to their gaming behaviour. This part not only shows how uneasy the gamers feel when their gaming practices come into conflict with social norms and expectations. It also reflects on the influence of the addiction-concept on the gamer's self-definitions. A second step discusses the underlying, latent motives of the gaming behaviour in the biographical context which sustain the behaviour along with the associated biographical consequences.

After presenting the two cases, both analyses are looked at in a short interim conclusion in terms of their theoretical implications for the social science study of the phenomenon of video game and internet dependency.

\section{Mathias}

\section{Biography}

Mathias is born in 1973 in western Germany as the second son of a 29 year-old secretary and a 31 year-old office worker. He is seven years old when his parents divorce and Mathias moves with his three-year-older brother and their mother to live with her later second husband some 200 kilometres from their home town. Their contact with their father dwindles to three or four visits a year, with Mathias always travelling to stay with his father. At around this age, Mathias has his first contact with video and computer games. He plays simple adventure games on a Commodore 16, and then goes on copying game programmes from magazines and programming his own small games.

17 At the age of 15, Mathias meets his first girlfriend. He terminates their relationship about a year and a half later. After that, he starts to play the guitar and learns to dance.

Mathias goes to Gymnasium (grammar school), does his Abitur (upper secondary leaving certificate) and then trains as a bank clerk. He meets his second girlfriend during his training. The video games are still part of his everyday life as they are joint activities with his girlfriend. At the end of his training, Mathias and his girlfriend study for a degree in social work. As they start working after their introductory year, Mathias begins a second degree course and studies social sciences. After seven years in his relationship, Mathias separates from his partner and leaves the home they have shared. He begins psychotherapy to cope with depression. Once the therapy is completed, he goes to study in another European country. Six months later, he becomes involved in an educational project. There, he meets a woman who is in a relationship with another man.

19 After his year abroad, Mathias returns to Germany and works on various projects and sometimes going travelling in between. After two years in what he calls the "waiting" position, Mathias finally gets together with the woman he met abroad - she had ended the relationship with her former partner. Mathias works "in education" (in a part-time 
position) and also takes on freelance work. They move in together and she gets pregnant.

At the time of the interview, Mathias is 37 years old and has been married to his partner for six months. They have two sons aged three and four. Mathias is unemployed and his wife, an occupational therapist, is also at home. The family is in a difficult situation financially. Video games like the real-time browser game Farmerama and a variety of other games on an internet gaming platform play an important role in his life.

\section{Analysis}

\section{Gaming Practice}

21 At the time of the interview, Mathias has been playing the real-time browser game Farmerama for about one and a half years and has invested real money in an attempt to increase his success. He has been playing a variety of casual games for a lot longer. These are largely skill and logic games on an internet platform where he competes against other players. He plays for money, which pushes his gaming behaviour more in the direction of gambling.

In the case of Farmerama and the casual games, Mathias has little interest in the actual content of the game and the social interaction involved is of no importance. Rather, his priority is "trying to .. reach the next level". His gaming practice is focused on achieving new goals. With Farmerama, it is about managing new tasks, while with the casual games it is the competition with new players. In both cases, the other players are seen only as the measure against which to pitch his performance. Thus, although they are real people, they are exchangeable and have no relevance as individuals.

Mathias says he spends somewhere between 2.5 and 4.5 hours on these games every day. According to KFN's CSAS-II assessment, he is currently classified as dependent.

\section{Self-Analysed Gaming Behaviour}

24 Throughout the interview, Mathias talks in a very self-reflective way, taking on the role of an expert on himself. This could have something to do with his experience of therapy and with his education and social science studies. With regard to his computer gaming behaviour, Mathias presents himself largely as an expert who sees through both the gaming mechanisms and his own behaviour. When looking at his biography as a whole, he identifies various phases in relation to computer gaming:

„Erm .. I think, if I .. if I were an alcoholic, you'd probably say I was an episodic drinker. /Uh-huh./ There are just times, y'know, when I play a lot. When it doesn't do me good. Time, money. / Uh-huh./ I guess you could say it does me harm. Erm, but then there are duller times when it .. just isn't important." ${ }^{\text {"13 }}$

Based on Mathias' self-analysis, he is currently in one of his "dependency" phases. His analogy of an "episodic drinker" implies, however, that these are followed by long phases of "sobriety". The clarity with which Mathias on a manifest level describes his behaviour contrasts with the latent message. This already becomes visible when taking a closer look at this sequence. On the one hand Mathias qualifies his gaming habits as time- and money-consuming. This is not yet problematic in itself but becomes a problem when confronted with social rules and normative expectations known and internalised by Mathias and in this situation represented by the interviewer. This 
interpretation is supported by the changes of the narrative perspective: to judge and classify his behaviour he takes on an external perspective ("you'd probably say" or "you could say it does me harm"). illustrates that for him, the game fulfils a specific function. This does not manifest itself in the interview material, but is latently present and stands in relation to an underlying tension that traverses Mathias' entire biography: one pole of this underlying tension involves Mathias' striving for social integration (both among peers and as part of a couple) which, where he achieves it, is often linked with the feeling of being controlled by others and being hemmed in, and not being able to develop freely. The other pole involves the phase of self-determination and "being at one with himself" quite apart from social relationships. The following sequence is a fitting example:

"There have been, mmmm, moments, where that has changed. Well, when it comes to friendships and stuff ... that was when (1) erm (2) during puberty, when I had, like, ... er, contact with .. a clique. (1) Then, well .. erm .. yeh, I developed very 
different relationships. And also, erm, had very different abilities to develop relationships. (1) Erm (hesitant, considering) (8) Back then, I (hesitant) had .. ff, I don't know, when I was 15 or so, my first .. relationship, which (1) (breathes in), erm (1), wasn't really that happy considering it was a teenage love, I mean a first love /Uh-huh./ (laughs briefly), but (takes a deep breath) even though it lasted quite a long time. About one and a half years all told. /Uh-huh./ Erm .. and .. from then (1) erm (1), well .. I felt, well, isolated in that relationship because the clique had disbanded .. (takes a deep breath) (1) erm (1) and after I'd (1) (hesitant) .. ended the relationship, well .. erm (2) I got really interested in lots of things. I kind of (1) "blossomed" (1) .. afterwards. (1) Erm and got involved in lots of (1) things which I then .. erm (3) wanted to get something out of. I started ... to play the guitar and I learned to dance. All those kinds of things, like."

Throughout the entire interview, Mathias traces his difficulties in finding social connections all the way back to his early childhood. He describes himself as a lonely, neglected child - both in relation to his family and peers. In the sequence above, he refers to "moments" in which things were different. It is evident that Mathias does not describe a long-term change (he does not say: "then, at some point, the situation changed"). His choice of words points more to situational, isolated changes which to a certain extent jump out from the loneliness, and are limited to a certain phase in his life, namely puberty. Mathias' choice of words - "a clique" instead of "my group of friends" suggests that his status within that clique is more one of a casual visitor than a permanent member. His accounts of "developed relationships" and "abilities to develop relationships" sound rather stilted and laboured. Mathias' social integration in this phase, it appears, is limited even though he tries to make the opposite clear. The second field, apart from the clique, in which Mathias tests his new "ability to form relationships" involve a romantic relationship. Although he speaks of "teenage love", there is no evidence of him being in love in what he describes. He was unhappy and "isolated" in that relationship and yet it lasted "a long time". For Mathias, the ability to form a relationship seems to mean the ability to suffer.

The failure of his social relationships (the clique and being part of a couple) results, surprisingly, in a "blossoming". Mathias describes a significant turning point towards the positive which is linked to a withdrawal from the social circle. He now seems to seek happiness in things and in himself. He found that he was unable to "be at one with himself" as part of a social circle, that he felt controlled by others and had to change in order to participate. It seems as if he frees himself from the assumption of having to be socially integrated and instead pursues the things that interest him.

This interpretation is supported by the change in tone at the end of the sequence. While the first part of the biographical account was strongly characterised by passive constructions and laboured ways of expressing himself, Mathias suddenly portrays himself in a pro-active role. He formulates his words clearly and he becomes the active subject in his story. He decides what he does and wants to "get involved" in things and "use them". The separation from his girlfriend and the breaking apart of the clique allows Mathias to take charge of his life. He goes from "suffering" to "doing", from being controlled by others to taking control. Playing guitar and dancing are given as examples, as some of a range of things that Mathias gets "involved" in during that time. But it is evident that, while these are activities which are potentially social - dancing explicitly since one needs a partner to dance - they are not referred to as social activities. He seems rather to pursue the activity for the activity's sake rather than for the people and the social contact. 

he acknowledges his wife ${ }^{16}$ to the outside world and describes his family as the "centre" of his life, when describing his own gaming behaviour, he gives the impression that he feels stifled and burdened in his current biographical situation, particularly as regards his fatherly responsibilities. In contrast to Mathias' pro-family statements, there are the emotionally unfulfilled and oddly empty passages in the interview, in which Mathias talks about his specific day-to-day family life. For example, when asked what he means when he says that his family is "important" to him, he uses generalisations ( "when you have children, everything centres around them. And (sucks his breath in) there's, erm .. a reason for that." and, when trying to explain those reasons, he is unable to get away from the normative perceptions:

"Well, everything that (1), erm, when, when it comes to conflict, family .. is always .. er, the top priority. And that .. sometimes gets on your nerves. (1) /Uh-huh./ When it gets .. too, erm (1), yeh .. when it gets too much, but in principle, erm .. it's okay, that's how it should be. /Uh-huh./ I mean, simply because .. erm, yeh. (3) Yes. (quiet) (3) I don't know whether that's really much of an explanation. (2) I mean, simply through this .. this (slaps his thigh), erm (1), yeh. (7) /Uh-huh./ (1) Oh well."

His explanation of the importance of the family remains a mere expectation ("in principle, erm .. that's how it should be"), that cannot be met with experience, so that the story ends abruptly. This points to a reproduction of his old relationship patterns in his current relationship. He places himself and his needs completely beneath those of the family and becomes a "martyr" to the cause. This martyrdom is potentially critical in that it remains purely normatively justified. In his story, it is sometimes questionable to what extent Mathias actually meets his own expectations of himself as a father and whether in terms of his norms - similar to his attitude to work - it is largely the expectation that remains and the gaming gets in the way of their implementation. The function of the games against this backdrop goes beyond the relaxation function which Mathias himself places at the forefront. It appears more as a means of self-isolation within the relationship. Mathias escapes into the gaming world in order to "shut himself off" (primarily from the children, but also from an unsatisfactory work situation), ${ }^{17}$ because his normative convictions forbid him to address the problems let alone openly pursue his own interests (and, for example, leave the relationship). The gaming itself poses no subjective breach of the family norm as far as Mathias is concerned (unlike the way it does with the working norm), but rather of the fatherly responsibilities and the exhaustion suffered as a result of fulfilling them.

Mathias' specific gaming practice is also of importance in this regard. Taking account of the biographical tension, it becomes plausible why Mathias does not use the game as a socialisation instrument and why the social aspect of the game is of no consequence to him. For him, it is more a "challenge" and a place to prove/test himself. As such, it can be seen as a social orientation towards performance, a "Pflicht zum Erfolg"18 (Neckel 2008) which is relevant to Mathias and, for example, is evident in his educational biography and his work-related expectations. What stands out is that Mathias in

RESET, 2 | 2013 
describing his gaming behaviour uses the rhetoric of the expert and in that role does not link his gaming behaviour to his current work situation. In fact, Mathias in his biographical account rarely places his gaming behaviour in any relation to his biography. First, he speaks of his relationships and only when asked does he separated from the biography told so far - describe his gaming history. ${ }^{19}$ Only in the description of his daily activities as outlined in the excerpts presented earlier do everyday life and gaming come into contact and cause his self-image to crumble. Mathias does not draw a systematic relationship between the two areas. This is consistent in that it would throw the fragile relationship off balance.

The analysis indicates that Mathias' gaming behaviour is biographically functional and convenient in that it opens a door within the relationship, allowing him to break free from being controlled by others and giving him the feeling of being "at one with himself" and being in charge of his own life. Thus, it supports the constellation in that moment. At the same time, it prevents any other tackling of the problems. The couple, or the family, are successively separated and the question of a new job is not systematically addressed. The normative perceptions and everyday practice are not brought together, but drift further and further apart.

\section{Simone}

\section{Brief Biography}

Simone is born in 1981 in a small town in eastern Germany. She is the only child of a working class family. When she is nine, her parents separate and later divorce. Simone moves out of the family home with her mother. Shortly afterwards, her mother commits suicide and Simone goes to live with her father. Her father succumbs more and more to alcohol and forces his daughter into the role of a housewife. The situation is desolate, the father regularly drinks away the housekeeping money, sometimes there is not even enough for food and coal. The former grammar school pupil has stopped going to school. At the age of 16 , Simone finally goes to child welfare services and asks for help. She is placed in sheltered housing and cuts off all contact with her father.

Simone's situation stabilises in the children's home. She goes back to school and takes up a few hobbies. The boys in her house group introduce her to video games. She leaves school with her Realschulabschluss (lower secondary leaving certificate), even attains her Abitur (upper secondary leaving certificate) and enters vocational training. Simone then lives in her own apartment and has her first boyfriend. Video games remain part of her everyday life. When with her boyfriend, she plays on his Playstation "for relaxation". In 2001 she uses her first wages to buy the Playstation2 which has just come onto the market.

41 During her training, Simone becomes ill while still in her probation period and is unable to go to work for a long time, but she continues to attend technical college. She is fired from her job. After a brief period of unemployment and a job creation scheme in a nursery school, Simone starts in a new apprenticeship which sees her moving to a nearby town. She breaks off this apprenticeship after 18 months, moves back to her home town and meets another man. She is unemployed, but receives placements on the odd job creation scheme and one-euro jobs ${ }^{20}$ from the job centre. 
42 After a two-year relationship, Simone moves in with her boyfriend in 2008. In October of that year, they start to play World of Warcraft (WoW), an online multiplayer role playing game. Simone has been unemployed for three years and is financially dependent on her boyfriend.

In 2009, Simone meets Thomas in WoW. He lives in a small town in western Germany. They belong to the same guild. They get to know each other through the game, call each other and chat online. In September 2010, Thomas takes the train to visit Simone and pick her up. Simone goes with him, packing just her essentials in a case. They stop playing WoW. At this point of the interview, Simone has been living with Thomas in his one-room apartment, is looking for work and for a small place of her own.

\section{Analysis}

\section{Gaming Practice}

In World of Warcraft, Simone's gaming behaviour is extremely success-focused. Similar to Mathias, she sets about tackling the challenges presented by the game. Meeting those challenges is, however, not the aim, not the reason for her efforts. Simone meets them primarily in order to make other players notice her and make herself attractive as an opponent. "You, you always have to make sure that you're always good and that people notice you. / Uh-huh./ So that (mumbles) someone remembers you, and .. picks you at random./ I: Yes./. Simone wants to "be noticed" by performing well in the game. The signs emerging at this point are confirmed in the further analysis: Simone plays in order to gain social recognition. For her, in contrast to Mathias, other players are not just opponents, but partners and, more importantly, those who recognise and value Simone's performance in the game.

As opposed to Mathias, at the time of the interview Simone has not played for three months. During her two-year gaming period, she spent more than six hours a day in World of Warcraft. According to CSAS-II, she was video game dependent during that time.

\section{Self-Analysed Gaming Behaviour}

As a former player, Simone sees her gaming behaviour very differently from Mathias. Looking back, she assesses her past gaming practice as problematic. For example, throughout the interview she talks explicitly of "dependency" and says that, from her current perspective, her World of Warcraft time was:

“That's /I: Uh-huh./ .. it's dangerous, you forget everything, even .. the things that were always really important, /I: Uh-huh./ .. and .. but what you don't realise at the time, looking back is - I'm realising it for the first time, hey, how, how, awf=awful it really was. /I: Uh-huh./ It's .. really crazy. How quickly you .. (deep sigh) .. yeh, the loss, I mean .. you lose touch with reality. /I: Uh-huh./ It's really bad."

Simone views her gaming as a period in which she lost touch with reality and failed to satisfy her own needs. Retrospectively she flags her gaming behaviour clearly as a problem and pathologises it ("dangerous", "bad") whereas while playing World of Warcaft she didn't experience it as a loss. It would go beyond the scope of this paper to trace this change of view in detail. But it seems to suggest itself that Simone's retrospective self-labeling as ex-dependent is useful to legitimize her intensive former occupation with the game to an external power: the drug and its powerful mechanisms. 
It fits in the picture that she only pathologises her gaming practices when reflecting on them. On the other hand, while describing what she actually did, she dives back into the gaming world and its power of attraction becomes visible.

\section{Gaming in the Biographical Context} "weeklies". They have to be tackled in groups of 10 or 25 players, and are only available for that specific week. The game sets the pace in which the challenges have to be met. As a reward, the players receive additional "items" for their characters (in the broadest sense a kind of currency used in the game). Players have the option not to meet the challenge, but that means falling behind those who do. In Simone's choice of wording, in her back and forth between "can", "must" and "want to", the ambivalence between obligation and compelling need on the one hand, and self-motivation on the other become very clear. Initially, the game simply throws up the challenges and does not biographical analysis shows that Simone's biography is characterised by strong discontinuity, uncertainty and numerous failed relationships. Through the loss of significant reference persons, she has to grow up "prematurely". In doing so, Simone develops a strong "get on with it" attitude and a "pick yourself up" mentality. This is seen in her decision, at 16, to go to the child welfare office, in her school career and in the many fresh starts she attempts in the working world. At the same time, her early independence gives rise to a closeness-distance problem. Simone finds it difficult to cope with various presence-absence relationships. This applies both to couple relationships and to role-type social relationships as in the work context. In her relationships, she sees herself making more effort than expected and expects at least the same level of effort from the other side. And she is repeatedly disappointed and does not receive the recognition and esteem she seeks. in a phase of stagnation and has no prospects of change. She has been unemployed for three years and has been living in a relationship in which she is both unhappy and financially dependent. She also has several failed attempts at improving her work biography, unsuccessful personal relationships and numerous new starts in different towns. She has no social resources, neither family nor close friends.

Against this backdrop, gaming takes on a greater role in her life. When playing, Simone can demonstrate success - unlike in much of her life so far - and she receives attention and recognition from fellow players. And it is guaranteed. The precondition being, however, that she engages in the dynamics of the game - something I choose to call the "treadmill" effect. She is moved by the feeling of having to tackle new individual and group-based challenges to remain competitive and to retain her status as an attractive competitor - or as Simone would put it, to "stand out". That this involves a decided social dynamic which evolves through the group and is only fostered by the game mechanism, becomes clear when Simone says:

"A WoW week always began on Wednesdays, because a new weekly came out on Wednesdays. /I: Uh-huh./ Then you got extra items and that was .. always a battle, first a tenner or a 25 -er. You just had to try and make sure that you .. did them with your characters. You could, but didn't have to, but .. most players wanted to, like."

Here, Simone speaks of a type of challenge regularly thrown up in the game, known as 
obligate players to take them up. Other mechanisms in the background (e.g. disadvantages compared with other players) motivate individual players to actually do face the challenges week after week. Simone makes it clear that - at least at the level at which she plays World of Warcraft - it is a given that these challenges must be met, that it is a convention: "most players want to, like." To play and win at this level you must get on the treadmill.

As long as Simone does this, as long as she shows engagement and performs, she enjoys success. The risk of failure in World of Warcraft is calculable and thus relatively low, because the rules in the gaming world are clear and success is reliably linked to performance. Hence, the game is functional for Simone. The consequences of this gaming behaviour regarding her everyday life and her biography are, however, obvious: Simone neglects herself, hardly eats and loses over 10 kilos despite starting from average weight. Her relationship suffers as a result of both the partners' video game use, their communication is largely reduced to game-related issues, and activities they once enjoyed, such as membership of a table tennis club, are given up. Thus, playing video games gradually undermines their everyday life, something which upon reflection Simone herself sees as "losing touch with reality".

\section{Interim Conclusion - Further Thoughts}

53 In the case analyses, it has become clear that the phenomenon called VGD is much more complex than psychological scales and screening instruments can map. It could be shown that social processes play an important role in both cases as regards the evolvement and fixation of their game use. For Mathias, the social context outside the gaming world is the prime motivation (suffocating relationship and fatherly duties) and is relevant in understanding his gaming behaviour. In Simone's case, her gaming behaviour is a reaction to her biographical framework (lack of recognition and esteem), and is determined by a social dynamic within the game ("treadmill" effect).

Furthermore, the analysis reveals a lot of ambivalence regarding the gaming habits and self-analyses throughout the interviews - although both cases are or were clearly "dependent" on video games according to CSAS-II. For both Mathias and Simone video game use can be seen as a meaningful reaction to their specific biographical situation and their underlying problems. Thus their virtual practices are functional regarding the everyday and lifestyle problems they are struggling with. At the same time, we see that the use of online games retroacts on their lives and takes on a quality which makes the interviewees themselves at least feel uneasy. That has to do with the fact that through their gaming habits certain social values, norms and social expectations partly internalized by the interviewees are breached and no longer met. For Mathias this applies in particular for the norm to work. Surprisingly he does not have this feeling when it comes to his duties as father and husband. The reason for this may be that for him his gaming even stabilises the family. Furthermore, it seems like his wife does not complain about the situation. At least in the whole interview Mathias does not mention a single such complaint. Interestingly, Mathias does not mention significant others who judge his gaming habits during the whole interview. He rather refers to an anonymous general other ("you could say") - represented in the interview situation by the interviewer ${ }^{21}$. Although he self-labels (Thoits, 1985) as VGD on the manifest level, his self-analyses regarding his gaming habits, however, remain ambivalent. 

dependent" she feels that she lost touch with reality while gaming and therefore has the feeling she did not live a normal life during that time. From her point of view she completely deviated from the general expectation to live in reality, not to escape into virtual worlds and to take part in everyday life. This relates to Rob Covers idea that we talk of VGD because games are conceptualized as an "unreal" universe, which likens them to drugs, and thereby they become subjected to a discourse of drug addiction (Cover, 2006).

In the light of the above mentioned, it has become clear that we are dealing with a phenomenon with social implications which therefore deserves a social scientific reflection. A purely biomedical and psychological analysis of the phenomenon described as video game and internet dependency, like that which has dominated research so far, cannot take account of all these mechanisms and interrelationships.

\section{Theoretical Reflection and Conceivable Future Prospects}

57 It has been shown that social science and related disciplines' involvement in this research field, drawing upon the old traditions of social science addiction research, can enrich the debate and contribute to a better and more differentiated understanding of the phenomenon. It provides tools for research which goes beyond an - albeit fruitful historical investigation of the discourse and the cause of the phenomenon - as can already be observed in some instances (Cover 2006; Walter \& Schetsche, 2003); tools to reconstruct the empirical phenomenon itself. This is achieved for example by asking which everyday problems and situations are solved by virtual practices and with which biographical consequences this might be associated. That this perspective can be fruitful has been shown in the empirical accounts presented in this paper. Furthermore, with a view to Becker's career and process model, promising studies can be imagined that look at the evolvement and development of internet and video game dependency while assuming a contingent development rather than a deterministic one.

In any case, using social science studies to address the social conditions surrounding the phenomenon of video game and internet dependency and approaching VGD from an autonomous sociological perspective would certainly enrich the scientific debate. The past restriction of human and social studies to online activities themselves thus excluding the associated, problematic phenomenon is an unjustifiable self-exclusion on the part of the social sciences community. Failing to address a phenomenon for fear of placing too much emphasis on the medical-psychiatric paradigm cannot be in the interests of knowledge advancement. Neither would it be in the interest of supporting and advising people like Simone, whose gaming behaviour was accompanied by a worrying degree of weight loss and ignorance of bodily needs. Sociology should pose its genuinely sociological research questions in relation to the phenomenon and, withstanding pressure from practitioners in the psychology and medical fields, take free license to study the phenomena in an objective way. This does not, however, exclude any dialogue with neighbouring disciplines. On the contrary, we have seen that the debate within human and social sciences on the phenomena can deliver findings that genuinely relate to social inquiry and thus produce results which can in turn be used in an application-oriented approach. An example is the finding that social

RESET, 2 | 2013 
processes play an important role in the emergence and maintenance of VGD on various levels - and that those gamers are neither only Pavlovian dogs, conditioned by the games rewarding mechanisms nor necessarily people with mental or personality disorders. Ironically, something that psychoanalysts, behavioural and systemic therapists, unlike their colleagues in research, already take into account when treating people with VGD. Hence, sociological research and the desire to make results useful in addressing social and health policy issues need not be mutually exclusive. Human and social sciences should, therefore, rise to the challenge of addressing phenomena which to date have been determined by neighbouring disciplines. This paper could only make a small contribution on the way to reach this goal. Still much more theoretical thinking and empirical work need to be done. There are benefits to be had on all sides: Social sciences as well as psychology and medicine and, in particular, the persons concerned who might suffer from their VGD and seek help and who deserve a broad understanding of the phenomenon.

\section{BIBLIOGRAPHY}

American Psychological Association (2012). Internet Use Disorder, Retrieved 28.08.2012,from http://www.dsm5.org/ProposedRevision/Pages/proposedrevision.aspx?rid=573

BECKER Howard S. (1963). Outsiders. Studies in Sociology of Deviance, New York, The Free Press. CORNELIUSSEN Hilde G. \& RETTBERG Jill W. (2008). Digital Culture, Play, and Identity. A World of Warcraft Reader, Cambridge, MIT Press.

COVER Rob (2006). "Gaming (Ad)diction: Discourse, Identity, Time and Play in the Production of the Gamer Addiction Myth", Game Studies the international journal of video game research 6 (1). Retrieved 23.01.2013, from http://gamestudies.org/0601/articles/cover.

DOLLINGER Bernd (2002). Drogen im sozialen Kontext. Zur gegenwärtigen Konstruktion abweichenden Verhaltens, Augsburg, MaroVerlag.

DOLLINGER Bernd \& SCHMIDT-SEMISCH Henning (2007). Sozialwissenschaftliche Suchtforschung, Wiesbaden, VS-Verlag.

FRITZ Jürgen, LAMPERT Claudia, SCHMIDT Jan-Hinrik \& WITTING Tanja (eds.) (2011). Kompetenzen und exzessive Nutzung bei Computerspielern : Gefordert, gefördert, gefährdet, 61 ed. Berlin, Vistas Verlag.

GENTILE Douglas A., CHOO Hyekyung, LIAU Albert, sIM Timothy, LI Dongdong, FUnG Daniel \& KHOO Angeline (2011). "Pathological Video Game Use Among Youths: A Two-Year Longitudinal Study", Pediatrics, 127 (2), pp. 319-329.

GRIFFITHS Mark \& HUNT Nigel (1998). “Dependence on video games by adolescents”, Psychological Reports 82 (2), pp. 475-80.

GROENEMEYER Axel (2008). Eine schwierige Beziehung - Psychische Störungen als Thema soziologischer Analysen. Soziale Probleme. Zeitschrift für soziale Probleme und soziale Kontrolle, 19 (2), pp. 113-135. 
GRÜSSER Sabine M. \& THALEMANN Ralf (2006). Computerspielsüchtig? Rat und Hilfe, Bern, Huber.

HAHN André \& JERUSALEM Matthias (2001a). « Internetsucht : Reliabilität und Validität in der Online-Forschung ", in Theobald, Axel, Dreyer, Marcus, Starsetzki, Thomas (eds.), Handbuch zur Online-Marktforschung. Beiträge aus Wissenschaft und Praxis, Wiesbaden, Gabler, pp. 1-21.

HAHN André \& JERUSALEM Matthias (2001b). « Internetsucht : Validierung eines Instruments und explorative Hinweise auf personale Bedingungen ", in Theobald, Axel, Dreyer, Marcus, Starsetzki, Thomas (eds.), Handbuch zur Online-Marktforschung. Beiträge aus Wissenschaft und Praxis, Wiesbaden, Gabler, pp. 213-233.

HERMANNS Harry (1991). « Narratives Interview », in Flick Uwe, Kardorff von Ernst, Keupp Heiner, Rosenstiel von Lutz \& Wolff Stephan (eds.), Handbuch Qualitative Sozialforschung, München, Psychologie Verlags Union.

HOHL Joachim \& KEUPP Heiner (1991). « Normalität und Abweichung als alltgliche Herstellungen », in Flick Uwe, Kardorff von Ernst, Keupp Heiner, Rosenstiel von Lutz \& Wolff Stephan (eds.), Handbuch Qualitative Sozialforschung. Grundlagen, Konzepte, Methoden und Anwendungen, München, Psychologie Verlags Union.

KLEIN Lutz (1997). Heroinsucht : Ursachenforschung und Therapie. Biografische Interviews mit Heroinabhängigen, Frankfurt/ New York, Campus.

KLOPPE Sylvia. (2004). Die gesellschaftliche Konstruktion der Suchtkrankheit. Soziologische und philosophische Aspekte der Genese vom traditionellen Drogengebrauch in der Vormoderne bis zum Konstrukt des krankhaften Drogenmissbrauchs in der Moderne, München, Martin Meidenbauer.

KUSS Daria \& GRIFFITHS Mark (2012). "Internet gaming addiction: A systematic review of empirical research", International Journal of Mental Health and Addiction, 10, pp. 278-296.

KÜSTERS Ivonne (2009). Narrative Interviews. Grundlagen und Anwendungen, vol. 2, Wiesbaden, VSVerlag.

LANE Christopher (2006). "How Shyness Became an Illness: A Brief History of Social Phobia”, Common Knowledge, 12 (3), pp. 388-409.

NECKEL Sighard (2008). Flucht nach vorn. Die Erfolgskultut der Marktgesellschaft, Frakfurt am Main/ New York, Campus Verlag.

OEVERMANN Ulrich, ALERT Tilman, KONAU Elisabeth \& KRAMBECK Jürgen (1979). "Die Methodologie einer "objektiven Hermeneutik" und ihre allgemeine forschungslogische Bedeutung in den Sozialwissenschaften", in Soeffner Hans-Georg (eds.), Interpretative Verfahren in den Sozial- und Textwissenschaften, Stuttgart, J.B. Metzler.

OLSON Gary A. (1991), "The Social Scientist as Author: Clifford Geertz on Ethnography and Social Construction", Journal of Advanced Composition, 11 (2), pp. 245-268.

PEELE Stanton (1985). The meaning of addiction. An unconventional view, San Francisco, Jossey-Bass. PEELE Stanton \& BRODSKY Archie (1991). Love and Addiction, Signet.

PRZYBORSKI Aglaja \& WOHLRAB-SAHR Monika (2008). Qualitative Sozialforschung : Ein Arbeitsbuch, München, Oldenbourg.

REHBEIN Florian, KLEIMANN Mattjas \& MÖSSLE Thomas (2010). “Prevalence and Risk Factors of Video Game Dependency in Adolescence: Results of a German Nationwide Survey", Cyberpsychology, Behavior, and Social Networking, 13 (3), pp. 269-277. 
REICHERTZ Jo (2004). “Objective Hermeneutics and Hermeneutic Sociology of Knowledge”, in Flick Uwe, Kardorff von Ernst \& Steinke Ines (dir), A companion to Qualitative Research, London, Sage, pp. 290-295.

RUMPF HJ, MEYER Christian, KREUZER Anja \& JOHN Ulrich (2011). Prävalenz der Internetabhängigkeit (PINTA), Report to the German Ministry of Health, Lübeck.

SCHMERL Christiane (1984). Drogenabhängigkeit. Kritische Analyse psychologischer und soziologischer Erklärungsansätze, Opladen, Westdeutscher Verlag.

SCHMIDT B., ALTE-TEIGELER A. \& HURRELMANN K. (1999). “Soziale Bedingungsfaktoren von Drogenkonsum und Drogenmißbrauch", in Gastpar Markus, Mann Karl \& Rommelspacher, Hans (dir.), Lehrbuch der Suchterkrankungen, Stuttgart/New York, Georg Thieme Verlag, pp. 50-69. SCHMIDT Jan-Hinrik, DROSSELMEIER Marius, Wiebke ROHDE \& Jürgen FRITZ (2011). "Problematische Nutzung und Abhängigkeit von Computerspielen", in Fritz Jürgen, Lampert Claudia, Schmidt JanHindrik \& Witting Tanja (eds.), Kompetenzen und exzessive Nutzung bei Computerspielern : Gefordert, gefördert, gefährdet, Berlin, Vistas, pp. 201-251.

SCHÜTZE Fritz (1983). "Biografieforschung und narratives Interview”, Neue Praxis, 3, pp. 283-293. STEIN-HILBERS Marlène (2007). “Selbstreflexive Ansätze der Drogenforschung”, in Dollinger Bernd \& Schmidt-Semisch Henning (eds.), Sozialwissenschaftliche Suchtforschung, Wiesbaden, VS-Verlag, pp. 35-45.

STRAUSS Anselm L. (1998). Grundlagen qualitativer Sozialforschung, Paderborn, Wilhelm Fink.

TAYLOR T. L. (2009). Play Between Worlds: Exploring Online Game Culture, Cambridge, MIT Press.

THALEMANN Ralf, wÖLFLING Klaus \& GRÜSSER Sabine M. (2007). “Specific Cue Reactivity on Video Game-related Cues in Excessive Gamers”, Behavioral Neuroscience, 121 (3), pp. 614-618. THATCHER Andrew, WRETSCHKO Gisela \& FRIDJHON Peter (2008). “Online flow experiences, problematic Internet use and Internet procrastination", Computers in Human Behaviour, 24, pp. 2236-2254.

THorts Peggy A. (1985). “Self-Labeling Processes in Mental Illness: The Role of Emotional Deviance", American Journal of Sociology, 91 (2), pp. 221-249.

WALTER Susanne \& SCHETSCHE Michael (2003). “Internetsucht - eine konstruktionistische Fallstudie”, Soziale Probleme. Zeitschrift für soziale Probleme und soziale Kontrolle, 14 (1), pp. 5-40. WERNET Andreas (2006). Einführung in die Interpretationstechnik der Objektiven Hermeneutik, 2. Auflage, Wiesbaden, VS-Verlag. ZINBERG Norman E. (1983). “Soziale Kontrollmechanismen und soziales Lernen im Umfeld des Rauschmittelkonsums", in Lettieri Dan J. \& Welz Rainer (eds.) Drogenabhängigkeit. Ursachen und Verlaufsformen. Ein Handbuch, Weinheim, Basel.

ZINBERG Norman E. (1984). Drug, Set, and Setting. The Basis for Controlled Intoxicant Use, New Haven, Yale University Press.

\section{NOTES}

1. Paradoxically, in treatment psychological practitioners - psychoanalysts, behavioural and systemic therapists - take the biography and social situation of their patients into account. In the case of video game dependency psychological research and treatment practice diverge. 
2. The instrument was developed and tested by Rehbein et al. It is based on the Internet Addiction Scale (ISS-20) by Hahn and Jerusalem (2001a, 2001b), which was extended and adapted to the issue of VGD (Rehbein, Kleimann \& Mößle, 2010). It consists of 14 items (4-point scale: 1 , incorrect, to 4, absolutely true) and covers the dimensions preoccupation/salience (4 items; e.g.: "During the time that I don't play video games, in my thoughts I am very much occupied with games." or "It happens that I'm virtually doing something completely different and then, without thinking, start a video game."), conflict (4 items; e.g.: "I am so frequently and intensively occupied with video games that sometimes I have problems in school/at work." or "People important to me complain that I spend too much time playing."), loss of control (2 items; e.g.: "I often spend more time playing video games than I planned."), withdrawal symptoms (2 items; e.g.: "If I can't play, I am irritable and dissatisfied."), and tolerance (2 items; e.g.: "I have a feeling that video games are getting more and more important for me."). The amount of time spent is not important to qualify as dependent according to that scale (see Rehbein, Kleimann \& Mößle, 2010).

3. "Dependency" is just one term used for the phenomenon. In the literature you can also find "addiction", "problematic" and "pathological" use or "internet use disorder" like in the suggestion for the upcoming version of the Diagnostic and Statistical Manual of Mental Disorders (DSM 5) (see APA 2012; Thatcher et. al., 2008;). All these terms basically refer to the same psychiatric concept which includes criteria like salience/preoccupation, tolerance, loss of control, withdrawal and continued use despite knowledge of negative consequences. "Excessive" use on the other hand is often differentiated from them as it refers to the amount of time spent with the activity without pathological background (see Rehbein, Kleimann \& Mößle, 2010).

4. Furthermore, psychology fighting to be accepted as an empirical science focused more and more on quantitative research methods including experimental studies.

5. Original German quote : „Die Rolle der Umgebung wird auch weiterhin bagatellisiert, weil sich die Forschung vorwiegend entweder auf die pharmazeutischen Eigenschaften der Droge und die durch sie bewirkten Gesundheitsrisiken oder auf den Persönlichkeitsverfall von Individuen, die ihren Konsum nicht unter Kontrolle haben, richtet"

6. Original German quote : „Infolge [der] Hegemonie [einer objektivistischen Psychopathologie] blieb eine genaue phänomenologische Rekonstruktion psychischer Störungen auf der Strecke, vor allem eine Rekonstruktion der subjektiven Bedeutungen, die psychische Devianz für die Person selbst, ihre Angehörigen oder diejenigen Menschen bedeutet, mit denen sie ihren Alltag teilen."

7. Original German quote : „Dies schließt selbstverständlich auch die genaue und differenzierte Analyse sozioökonomischer Faktoren, psychischer Dispositionen und besonderer Belastungsmomente in der bisherigen Lebensgeschichte von Konsument/innen ein. Die Analyse von Drogenabhängigkeit muss so facettenreich und nuanciert erfolgen, wie sie sich in der Realität darstellt.“

8. Original German quote : "insofern, als der Süchtige die Normen und Handlungsregelungen, die in der Gesellschaft für den Umgang mit dem Suchtobjekt gelten, überschreitet “

9. Lutz Klein (1997) used a similar approach in his study on heroin addicts.

10. I am aware that scales and tests like the CSAS-II are part of the "birth" of VGD and its definition. They are not neutral in normative terms and thus their results cannot be taken for granted. Nevertheless, my research question made it necessary to somehow identify gamers who qualify as "dependent" before breaking up this simple label through analyses.

11. That the majority of the recruited gamers does not qualify as "dependent" according to CSASII scale suggests that the wide recruitment strategy was successful in terms of addressing gamers in general and not only those who self-label as addicts. 
12. Whereas Simone talks very open about her life and biography Mathias anonymizes most of his biography himself by giving very vague information, explaining he does not want to be recognizes by prospective employers.

13. Transcription: Underlined - emphasis; speaking pause - two dots for short pauses, number of seconds in brackets for long pauses; slashes, e.g. /Uh-huh/ - short statement by the other person. Analysis and interpretation follow the original (German) version.

14. Elsewhere, Mathias compares his video game use explicitly with television: "Then (quiet, considering) .. with the games, it's then .. y'know, that .. yeh .. that the activity is there, that is (1) somehow (considers) (1) like television, I mean, we don't actually have a television, but .. even so, er .. the Situation is the same, that you .. do something that you can also do when you're really tired. /Uh-huh./ That means, well, (1) from (2) it er (considers) (1) yeh. (2) You can even do it .. when you're whacked. Or when you would usually, if you had no computer, no television .. would probably just go to bed or something. /Uh-huh./ Then .. playing video games is something you could do."

15. This becomes evident when he describes the relationship: "that, er .. strengthened me .. but also suffocated me. (1) I mean, (1) in that (1), .. for me personally, because there was really no space. /Uh-huh./ (2) It was nearly all us and .. and hardly any me".

16. For example, he says: "Because it was clear for me then, that I wanted to be with her and she then .. well (1), erm (1) laid the foundation for it to happen and and erm (1) was sure it was what she wanted. It didn't really matter, that she got pregnant so quickly. /Uh-huh./ (1) Erm (quiet) .. in the meantime we've got two kids. (1) And .. then we just said ... a couple of months ago .. let's get married.".

17. Mathias speaks of isolation and shutting off when reflecting on his gaming behaviour. For him, this isolation is only for the moment, to free himself of the stress of looking after the children and is thus closely linked to the relaxation function. He does not focus on the underlying tension of his biography, as is evident here: "That is (considers) (1) is, I think, just the ways it is, that when you have kids around you all the time, then .. then you .. somehow ... that is the second advantage, I think, of this computer stuff.. have something where you are also (1) erm (quiet) .. somehow a bit isolated .. when playing. / Uh-huh./ I mean, you (1) er (1), you .. you shut yourself off .. from from outside noise .. you distance yourself a bit or .. outside noises, outside influences /Uh-huh./ in general. And after a .. a day like that .. it's what you need. /Uh-huh./ At least that's how it is for me.".

18. Free translation: "obligation to succeed".

19. This is supported in that at the start of the interview, a noticeable interaction occurs regarding the content of the interview. Mathias assumes a kind of expert interview on gaming and only reluctantly responds to the biography-related questions posed by the interviewer. He thus signals that he sees his gaming behaviour as having nothing to do with his biography.

20. One-euro jobs are part of the German Hartz concept to increase employment and to decrease welfare costs. These working opportunities were invented to aid the long term unemployed in becoming accustomed to regular work again. They are called one-euro jobs because participants receive an additional cost compensation which is about one Euro per hour.

21. Although I tried to avoid framing on addiction and problematic aspects when advertising for the study and during the interview I was not able to completely abandon those aspects - if only because being a representative of the Criminological Research Institute of Lower Saxony. Furthermore, there was a lot of media reporting on VGD going on in Germany by the time the interviews were conducted. That is visible throughout almost all interviews. 


\section{ABSTRACTS}

This article starts with the observation that the scientific and social debate on video game and internet dependency is driven by naturalist research standpoints used in psychology and neuroscience, while sociology and related disciplines in human and social studies widely ignore the phenomenon. This can be viewed as an unnecessary thematic self-exclusion of sociology regarding its fruitful former discussion and analyses of dependency in general. After highlighting some of these studies, the article gives insight into an empirical research project which partly takes up this sociological tradition and transfers it to video game dependency: as part of a qualitative submodule of a study by the Criminological Research Institute of Lower Saxony (KFN) on behalf of the Lower Saxony Ministry of Science and Culture, 15 biographical narrative interviews were conducted with video gamers of both sexes who, according to the CSAS-II screening instrument and/or self-analysis, are currently video game dependent or have been at some time in the past. Based on empirical analysis from this project, it is argued that video game and internet dependency not only deserve sociological consideration, but that a sociological analysis is vital in order to arrive at a more differentiated understanding of these complex phenomena.

Cet article part du constat que le débat scientifique et social sur le jeu vidéo et la dépendance à Internet est principalement nourri par des perspectives de recherche naturalistes utilisées en psychologie et en neurosciences, tandis que la sociologie et les disciplines connexes des sciences humaines et sociales tendent à ignorer la question. Cela peut être considéré comme une regrettable forme d'auto-exclusion de la sociologie d'un domaine qu'elle avait pourtant investi de manière fructueuse dans le passé. Après avoir souligné certains de ces travaux, l'article propose un aperçu d'un projet de recherche empirique qui reprend en partie cette tradition sociologique pour la transférer à l'étude de l'addiction au jeu vidéo. Dans le cadre du sous-module qualitatif d'une enquête menée par l'Institut de recherche criminologique de Basse-Saxe (KFN) au nom du Ministère de la Science et de la Culture, quinze entretiens biographiques ont été menés avec des joueurs de jeux vidéo des deux sexes qui, selon leur résultat au CSAS-II ou selon leur propre point de vue, sont actuellement dépendants au jeu vidéo ou l'ont été à un moment de leur vie. Sur la base de l'analyse empirique de ces cas, nous soutenons que non seulement le thème de l'addiction aux jeux vidéo et à Internet mérite l'attention de la sociologie, mais que l'analyse sociologique est indispensable pour parvenir à une compréhension plus nuancée de ces phénomènes complexes.

\section{INDEX}

Mots-clés: addiction aux jeux vidéo, méthode qualitative, jeu problématique, sociologie

Keywords: videogame dependency, qualitative method, Internet gaming disorder, sociology

\section{AUTHOR}

\section{NADINE JUKSCHAT}

Kriminologisches Forschungsinstitut Niedersachsen 